\title{
PERLINDUNGAN HUKUM TERHADAP PEMEGANG KARTU \\ E-MONEY SEBAGAI ALAT PEMBAYARAN DALAM TRANSAKSI \\ KOMERSIAL
}

Oleh :

Ni Nyoman Anita Candrawati

Mahasiswa Magister Ilmu Hukum Universitas Udayana

\begin{abstract}
One means of electronic or non-cash payments are by using electronic money card (e-money). Value of money is stored electronically and issued on the basis of the value of money paid to the holders of the provider. The money is used as a means of payment, but not the deposit as stipulated in the Banking Law, so it is not guaranteed by Saving Guarantee Institution (LPS).

There are two issues that were examined in this study, namely: the arrangements for electronic money card holders in e-money transactions and legal protection for the cardholder to perform e-money transactions. The research is a normative legal research using law and conceptual approach. Based on the results of studies conducted on the issue, the legal regulation of the form of electronic money stipulated in Bank Indonesia Regulation Number 11/12/PBI/2009 on Electronic Money, and through standard agreements governed by the provider, such as terms and conditions of the card holder. Legal protection for the cardholder is required to ensure the equality of the provider and the card holder, including legal protection against the misuse of e-money card that can be detrimental to the holder, through preventive and repressive legal protection.
\end{abstract}

Keywords: electronic money, payment system, card holder, forms of regulation, legal protection.

\section{PENDAHULUAN}

\section{Latar Belakang}

Perkembangan teknologi

membawa perubahan pada kegiatan perdagangan, yakni adanya kebutuhan masyarakat atas suatu alat pembayaran yang aman, cepat dan efisien dalam bertransaksi. Alat pembayaran mengalami perubahan 
dimulai dari alat pembayaran dalam bentuk uang tunai berupa logam dan kertas konvensional, kiri telah berkembang dalam bentuk alat pembayaran elektronik.

Dalam penggunaan
pembayaran
elektronik, perlu
diperhatikan bahwa teknologi yang
digunakan merupakan hasil cipta
manusia yang mempunyai
kelemahan-kelemahan yang dapat
disalahgunakan

penggunaannya. Hal ini yang perlu mendapat kepastian dari jaminan hukum terhadap para penggunanya.

Alat pembayaran elektronis atau non tunai ini dapat diklasifikasikan ke dalam alat pembayaran menggunakan kartu yaitu kartu kredit (Credit Card), kartu ATM (Automated Teller Machines Card), kartu debit (Debit Card) dan kartu penyimpan dana (Stored Value Card). ${ }^{1}$ Kartu penyimpan dana atau

\footnotetext{
${ }^{1}$ Dalam Peraturan Bank Indonesia Nomor 10/8/PBI/2008 tentang Perubahan atas Peraturan Bank Indonesia Nomor 7/52/PBI/2008 tentang Penyelenggaraan Kegiatan Alat Pembayaran Menggunakan Kartu, alat pembayaran dengan menggunakan kartu adalah alat pembayaran berupa kartu kredit, kartu Automated Teller
}

kartu prabayar selanjutnya diatur secara terpisah dengan alat pembayaran menggunakan kartu lainnya dan dikenal dengan nama uang elektronik (e-money). ${ }^{2}$ Perubahan klasifikasi ini dikarenakan uang elektronik dilihat dari pengertiannya bahwa kartu dapat diterbitkan oleh bank maupun lembaga selain bank, sedangkan alat

Machine (ATM), kartu debet dan kartu prabayar.

${ }^{2}$ Peraturan alat pembayaran menggunakan kartu saat ini diatur dalam Peraturan Bank Indonesia Nomor 14/2/PBI/2012 tentang Penyelenggaraan Alat Pembayaran Menggunakan Kartu yaitu menjadi kartu kredit, kartu Automated Teller Machine (ATM), kartu debet.

Uang elektronik diatur terpisah yaitu dalam Peraturan Bank Indonesia Nomor 11/12/PBI/2009 tentang Uang Elektronik (Electronic Money), dimana uang elektronik adalah alat pembayaran yang memenuhi unsur-unsur sebagai berikut :

1. Diterbitkan atas dasar nilai uang yang disetor terlebih dahulu oleh pemegang kepada penerbit.

2. Nilai uang disimpan secara elektronik dalam suatu media seperti server atau chip.

3. Digunakan sebagai alat pembayaran kepada pedagang yang bukan merupakan penerbit uang elektronik tersebut.

4. Nilai uang yang disetor oleh pemegang dan dikelola oleh penerbit bukan merupakan simpanan sebagaimana dimaksud dalam undang-undang yang mengatur mengenai perbankan. 
pembayaran menggunakan kartu lainnya hanya dapat diterbitkan oleh bank.

Uang elektronik (e-money) merupakan sebuah inovasi untuk kebutuhan transaksi pembayaran yang bersifat mikro (retail) yaitu pembayaran dalam jumlah sedikit. Penggunaan e-money hanya menempelkan kartu pada sensor alat yang disediakan penerbit pada pedagang (merchant) maka transaksi pembayaran berhasil dilakukan dengan pemotongan saldo yang ada pada kartu. Hal ini mempermudah konsumen karena tidak perlu membawa uang tunai jika ingin melakukan pembayaran, sehingga dapat mengurangi tingkat kriminalitas. Selain itu kartu e-money ini dapat dimiliki oleh nasabah maupun non nasabah dari bank penerbit, kartu juga dapat di isi ulang (top up)

Transaksi

menggunakan e-money tanpa proses otorisasi serta tidak berkaitan dengan rekening nasabah di bank, karena perolehan kartu e-money tidak memerlukan konfirmasi data atau personal identification number (PIN). Kehilangan kartu bukan merupakan tanggung jawab penerbit. Penerbit tidak dapat memblokir kartu yang hilang atau dicuri dan penerbit tidak akan mengganti saldo yang hilang atau dicuri tersebut, karena nilai uang yang tersimpan dalam kartu bukan simpanan pada bank penerbit.

Perlindungan hukum terhadap pemegang kartu e-money harus diberikan atas dasar semakin majunya ilmu pengetahuan dan teknologi dalam kegiatan pembayaran menggunakan sistem elektronik (e-payment system), sehingga dapat menghindari penyalahgunaan kartu e-money oleh pihak-pihak yang tidak bertanggung jawab. Diperlukan bentuk pengaturan bagi pemegang kartu dan perlindungan hukum untuk menjamin aspek keadilan bagi pemegang kartu uang elektronik dalam melakukan transaksi pembayaran sesuai dengan kebijakan pemerintah maupun peraturan yang dikeluarkan oleh Bank Indonesia sebagai lembaga pengawas kegiatan keuangan. 


\section{Rumusan Masalah}

a. Bagaimanakah pengaturan $e$ money sebagai alat pembayaran dalam transaksi komersial?

b. Bagaimanakah perlindungan hukum terhadap pemegang kartu e-money yang mengalami kehilangan kartu?

\section{Tujuan Penelitian}

\section{a. Tujuan Umum}

Untuk mengetahui dan memahami perlindungan hukum bagi pemegang kartu e-money sebagai alat pembayaran dalam transaksi uang elektronik.

\section{b. Tujuan Khusus}

1) Mengetahui pengaturan $e$ money sebagai alat pembayaran dalam transaksi komersial.

2) Untuk menganalisis perlindungan hukum yang dapat diberikan bagi pemegang kartu e-money jika kehilangan kartu.

\section{METODE PENELITIAN}

Metode yang digunakan adalah secara normatif. ${ }^{3} \quad$ Penelitian ini mengkaji permasalahan melalui peraturan perundang-undangan (the statute approach) yang berkaitan dengan pengaturan uang elektronik (e-money) dan ditinjau berdasarkan teori-teori dan ketentuan-ketentuan hukum yang mengaturnya serta berdasarkan pengertian-pengertian dan asas-asas yang relevan dengan permasalahan.

Sumber bahan hukum terdiri dari bahan hukum primer, sekunder dan tersier. ${ }^{4}$ Bahan hukum primer terdiri

3 Penelitian Hukum Normatif merupakan penelitian doktrinal yang mempergunakan sumber data sekunder, yaitu berdasarkan peraturan perundang-undangan.

Ronny Hanitijo Soemitro, 1995, Metodelogi Penelitian Hukum dan Jurimetri, Ghalia Indonesia, Jakarta, Hal. 9.

4 Bahan Hukum Primer merupakan bahan hukum yang mempunyai kekuatan hukum mengikat secara hukum. Bahan Hukum Sekunder yaitu bahan pustaka yang memberikan penjelasan mengenai bahan hukum primer. Bahan Hukum Tersier adalah bahan yang memberikan penjelasan terhadap bahan hukum primer dan sekunder. 
dari peraturan perundang-undangan yang berkaitan dengan masalah yaitu Kitab Undang-Undang Hukum Perdata; Undang-Undang Nomor 10 Tahun 1998 tentang Perbankan; Undang-Undang Nomor 11 Tahun 2008 tentang Informasi dan Transaksi Elektronik; UndangUndang Nomor 3 Tahun 2004 tentang Bank Indonesia; UndangUndang Nomor 8 Tahun 1999 tentang Perlindungan Konsumen; dan Peraturan Bank Indonesia Nomor 11/12/PBI/2009 tentang Uang Elektronik (Electronik Money). Bahan hukum sekunder yang digunakan berupa buku-buku atau literatur-literatur yang terkait dengan permasalahan, dan bahan hukum tersier meliputi kamus ataupun bahan yang diperoleh melalui media internet.

Seluruh bahan hukum tersebut dikumpulkan menggunakan metode sistematis kartu (card system) dimana kartu ini disusun berdasarkan permasalahan hukum yang dibahas.

Soerjono Seokanto dan Sri Mamuji, 2001, Penelitian Hukum Normatif Suatu Tinjauan Singkat, PT. Raja Grafindo Persada, Jakarta, Hal. 13.
Bahan hukum yang telah dikumpulkan tersebut dianalisis menggunakan teknik deskripsi dengan menguraikan kondisi permasalahan dan selanjutnya dievaluasi sesuai dengan teori dan peraturan perundang-undangan yang berkaitan dengan pengaturan alat pembayaran menggunakan uang elektronik (e-money).

\section{HASIL DAN PEMBAHASAN}

\section{Pengaturan Uang Elektronik} Sebagai Alat Pembayaran Dalam Transaksi E-Money

Uang elektronik merupakan suatu inovasi baru yang bertujuan untuk member kepraktisan dalam melakukan transaksi pembayaran. Uang elektronik tidak dapat disamakan dengan alat pembayaran berbentuk kartu seperti kartu ATM atau kartu debit, dan kartu kredit, karena penerbitannya tidak hanya dilakukan melalui bank tetapi juga lembaga selain bank, nilai uang elektronik dalam kartu disimpan dalam media untuk proses transaksi 
pembayaran. $^{5}$ Nilai uang yang tersimpan dalam media ini menurut Peraturan Bank Indonesia tidak dijamin oleh Lembaga Penjamin Simpanan (LPS) maka perlu adanya pengaturan terhadap perlindungan bagi pemegang kartu yang menggunakan uang elektronik sebagai alat pembayaran.

\section{Perkembangan masyarakat} menjadi salah satu kendala dalam penegakan dan penerapan hukum. Bila dikaitkan dengan peraturan perundang-undangan khususnya mengenai perlindungan terhadap pemegang kartu uang elektronik

${ }^{5}$ Dilihat dari media yang digunakan, ada dua tipe produk uang elektronik yaitu :

a. Prepaid card/kartu prabayar/electronic purses, dengan karakteristik nilai uang dikonversi menjadi nilai elektronis dan disimpan dalam suatu chip (integrated circuit) yang tertanam pada kartu. Mekanisme pemindahan dana dilakukan dengan cara memasukkan kartu ke dalam suatu card reader.

b. Prepaid software/digital cash, dengan karakteristik nilai uang dikonversi menjadi nilai elektronis dan disimpan dalam suatu hard disk computer. Mekanisme pemindahan dana dilakukan secara online melalui suatu jaringan komunikasi seperti internet, pada saat melakukan pembayaran.

R. Serfianto DP, dkk, 2012, Untung dengan Kartu Kredit, Kartu ATM-Debit, \& Uang Elektronik, Visi Media, Jakarta, Hal. 98. dalam transaksi e-money, bahwa hukum harus dapat merespon perubahan yang terjadi, artinya peraturan tersebut harus dapat mengakomodir permasalahan yang timbul dari adanya perkembangan zaman melalui penyempurnaan peraturan perundang-undangan khususnya dalam hal perlindungan hukum terhadap pemegang kartu uang elektronik.

Dalam kaitannya dengan uang elektronik (e-money), pembentukan peraturan perundang-undangan harus berlaku juga bagi pelaku usaha atau penerbit, dan adanya konsistensi terhadap peraturan dan pelaksanaannya. Aturan-aturan tersebut harus diumumkan dan dirumuskan secara jelas dan dapat dimengerti oleh pemegang kartu sebagai objek dari pengaturan tersebut, hal ini karena sistem transaksi elektronik merupakan transaksi dengan alat buktinya bersifat elektronik. $^{6}$

6 Niniek Suparni, 2009, CyberspacePeoblematika dan Antisipasi Pengaturannya, Sinar Grafika, Jakarta, Hal. 110-111. 
Permasalahan hukum dalam sistem elektronik akan terjadi apabila sistem pembayaran elektronik yang digunakan untuk melaksanakan transaksi elektronik (pembayaran) mengalami kegagalan dan mengakibatkan kerugian. Jika terjadi hal demikan maka pihak mana yang akan bertanggung jawab dalam kegagalan transaksi tersebut. Adanya bentuk tanggung jawab penyelenggaraan pembayaran elektronik menggunakan uang elektronik dimulai dari adanya hubungan hukum yang terjadi antara penerbit dan pemegang kartu dalam suatu perikatan.

Dalam pembelian kartu $e$-money pada penerbit, kartu akan dilengkapi dengan syarat dan ketentuan penggunaan kartu e-money tersebut. Syarat dan ketentuan tersebut menjadi suatu bentuk perjanjian antara penerbit dan pemegang kartu dalam penggunaannya pada transaksi e-money.

Salah satu acuan penting pada perlindungan pemegang pada Undang-Undang Perlindungan Konsumen yaitu dengan adanya peraturan mengenai pencantuman klausula baku pada perjanjian. $^{7}$ Dimana dasar peraturan dalam penggunaan alat pembayaran elektronik menggunakan uang elektronik adalah dengan menggunakan perjanjian baku, maka pencantuman klausula baku yang seimbang haruslah diatur.

Klausula baku biasanya dibuat oleh pihak yang kedudukannya lebih kuat, yang dalam kenyataannya biasa dipegang oleh pelaku usaha atau dalam kaitannya dengan perjanjian baku uang elektronik kedudukan yang lebih kuat dipegang oleh

\footnotetext{
${ }^{7}$ Perjanjian baku merupakan terjemahan dari standard contract, baku berarti patokan dan acuan. Mariam Darus mendefinisikan perjanjian baku adalah perjanjian yang isinya dibakukan dan dituangkan dalam bentuk formulir. Perjanjian baku merupakan konsep janji-janji tertulis yang disusun tanpa membicarakan isi dan lazimnya dituangkan dalam perjanjian yang sifatnya tertentu.
}

Dalam UU PK pasal 1 angka 10 mendefinisikan klausula baku adalah setiap aturan atau ketentuan dan syarat-syarat yang telah dipersiapkan dan ditetapkan terlebih dahulu secara sepihak oleh pelaku usaha yang dituangkan dalam suatu dokumen dan/atau perjanjian yang mengikat dan wajib dipenuhi oleh konsumen.

Mariam Darus Badrulzaman, 1978, Perjanjian Kredit Bank, Alumni, Bandung, Hal. 48. 
penerbit kartu e-money. Isi klausula baku sering kali merugikan pihak yang menerima klausula baku tersebut, yaitu pihak konsumen atau pemegang kartu e-money karena dibuat secara sepihak oleh penerbit. Bila konsumen menolak klausula baku tersebut ia tidak akan mendapatkan barang atau jasa yang dibutuhkan, karena klausula baku serupa akan ditemui di tempat lain. Artinya, dimanapun calon pemegang kartu e-money akan melakukan pembelian barang atau jasa uang elektronik maka penerbit akan memberikan klausula baku sebagai bentuk persetujuan pembelian dan penggunaan kartu uang elektronik. Hal tersebut menyebabkan konsumen atau pemegang kartu e-money menjadi lebih sering menyetujui isi dari klausula baku tersebut walaupun memojokkan. ${ }^{8}$

Dilihat dari penerbitan kartu $e$ money pada bank penerbit, syarat dan ketentuan tersebut mengikat bagi pemegang kartu selaku pengguna.

\footnotetext{
${ }^{8}$ Abdulkadir Muhammad, 1992, Perjanjian Baku dalam Praktik Perusahaan Perdagangan, PT. Citra Aditya Bakti, Bandung, Hal. 6.
}

Dengan melakukan pembelian kartu e-money tersebut, maka pemegang kartu dianggap telah menyetujui seluruh isi syarat dan ketentuan penggunaan kartu tanpa perlu menandatanganinya.

Pengaturan kegiatan pembayaran menggunakan uang elektronik ( $e$ money) sesuai kewenangan dari Bank Indonesia selaku Bank Sentral mengatur dalam Peraturan Bank Indonesia Nomor 11/12/PBI/2009 tentang Uang Elektronik (Electronic Money), dan sehubungan diberlakukannya Peraturan Bank Indonesia tersebut maka diatur pula dalam Surat Edaran dangan Nomor 11/11/DASP Tahun 2009 tentang Uang Elektronik (Electronic Money).

Peraturan Bank Indonesia dan Surat Edaran Bank Indonesia mengenai uang elektronik ini mengatur mengenai bagaimana syarat dan tata cara para pihak dalam uang elektronik demi kelancaran kegiatan uang elektronik dan perlindungan terhadap pemegang kartu. Hal ini diatur berkenaan dengan pengawasan terhadap penyelenggaraan kegiatan uang 
elektronik dan merupakan bentuk perlindungan terhadap pemegang kartu e-money.

\section{Upaya Hukum Bagi Pemegang} Kartu E-Money Dalam Melakukan Transaksi Uang Elektronik

Dalam hal hilangnya kartu (Lost/Stolen Card), kartu tetap dapat digunakan sampai pemilik sah memberitahukan kepada bank penerbit, namun kartu tersebut tetap dapat disalahgunakan oleh pihak lain. penyalahgunaan kartu oleh pihak lain ini dapat terjadi dengan pencurian oleh pihak lain maupun kelalaian dari pemilik kartu itu sendiri. Setelah kartu berada di pihak lain, penyalahgunaan tentu saja dapat digunakan dengan berbagai cara, salah satunya sepertli berbelanja langsung kepada merchant, karena ketika kartu hilang maka kartu dapat digunakan tanpa perlu dilakukan otorisasi oleh merchant dan tidak dapat dilacak keberadaan kartu tersebut.

Tingkat sekuritas pada e-money merupakan salah satu aspek penting mengingat kerugian yang dapat ditimbulkan baik bagi penerbit maupun pemegang kartu tersebut. Usaha kejahatan untuk menembus sistem security e-money bisa terjadi pada level pengguna, pedagang (merchant) ataupun penerbit, termasuk pencurian terhadap peralatan milik merchant atau pemegang kartu, pemalsuan kartu atau pesan (message), merubah data yang tersimpan dalam kartu atau isi pesan yang dikirimkan, dan juga dapat dilakukan dengan merubah fungsi software. ${ }^{9}$

\footnotetext{
${ }^{9}$ Beberapa bentuk pengamanan yang dapat dilakukan untuk melindungi produk $e$-money antara lain yaitu :

a. Penggunaan microchip yang bersifat tamper-resistant atau tahan banting untuk produk card based;

b. Penggunaan teknologi encryption, baik untuk produk card-based maupun software-based yang digunakan untuk otentifikasi peralatan maupun pesan-pesan yang dikirimkan serta untuk melindungi data yang tersimpan dari usaha-usaha pihak yang ingin melakukan perubahan;

c. Pembatasan nilai maksimum yang dapat disimpan atau yang dapat dibayarkan juga merupakan salah satu usaha untuk meminimalkan kerugian bila terjadi penyalahgunaan.
}

Bank Indonesia, 2001, Paper Kajian EMoney, Bank Indonesia, Jakarta, Hal 12-13. 
Dalam transaksi elektronik mengenai tanggung jawab harus dilihat pada prinsip-prinsip tanggung jawab dari sisi perlindungan konsumen. Tanggung jawab timbul karena seseorang atau suatu pihak mempunyai suatu kewajiban, termasuk karena undang-undang dan hukum (statutory obligation). Dari kewajiban (duty, obligation) akan lahir tanggung jawab. ${ }^{10}$

Dilihat dari transaksi elektronik yang dilakukan menggunakan kartu uang elektronik (electronic money/emoney) sebagai suatu produk, maka pedagang (merchant) bukan termasuk sebagai penyelenggara dari sistem elektronik itu sendiri. Sayangnya, masyarakat umumnya hanya melihat pedagang yang menjual produknya secara elektronik termasuk ke dalam penyelenggara sistem elektronik tersebut, padahal pedagang juga merupakan konsumen dari sistem elektronik yang digunakan untuk menawarkan barang kepada konsumen. Maka dapat

${ }^{10}$ N.H.T. Siahaan, 2005, Hukum Konsumen : Perlindungan Konsumen dan Tanggungjawab Produk, Panta Rei, Jakarta, Hal. 137. dikatakan pedagang (merchant) dan pemegang kartu merupakan konsumen dari penyelenggaraan sistem transaksi elektronik yang telah dikembangkan oelh suatu pihak tertentu (developer) atau diselenggarakan oleh suatu pihak tertentu (provider). ${ }^{11}$

Dalam penyelenggaraan kegiatannya, penerbit memiliki kewajiban sesuai dengan ketentuan Peraturan Bank Indonesia tentang Uang Elektronik yaitu :

1. Menerbitkan uang elektronik sesuai dengan nilai uang yang disetorkan pemegang kepada penerbit.

2. Mematuhi batas maksimum nilai transaksi dan batas maksimum nilai uang elektronik yang tersimpan sesuai ketentuan yang ditetapkan.

3. Adanya penggantian atas pembaharuan terhadap keterbatasan usia teknis

\footnotetext{
${ }^{11}$ Edmon Makarim, 2004, Kompilasi Hukum Telematika, PT. RajaGrafindo Persada, Jakarta, Hal. 342.
} 
media uang elektronik dengan tidak menghilangkan nilai uang elektronik yang tersimpan karena merupakan milik pemegang kartu.

4. Penerbit mencatat setiap identitas pedagang (merchant).

5. Adanya penerapan manajemen risiko keuangan dan risiko operasional.

6. Penerbit menginformasikan secara tertulis mengenai produk uang elektronik kepada pemegang.

7. Uang elektronik wajib diterbitkan dalam mata uang rupiah.

Penerbit uang elektronik (electronic money / e-money) wajib menerapkan prinsip perlindungan nasabah dalam menyelenggarakan kegiatannya dengan menyampaikan informasi secara tertulis kepada pemegang kartu. Kewajiban penyelenggara sistem pembayaran elektronik terhadap pemegang kartu uang elektronik (e-money) didasarkan bahwa penyelenggara dan pemegang kartu kedudukannya tidak sejajar dan bahwa kepentingan pemegang kartu e-money sangat rentan terhadap tujuan penyelenggara yang memiliki pengetahuan dan keahlian yang tidak dimiliki oleh pemegang kartu. ${ }^{12}$

Perlindungan hukum bagi pemegang kartu dapat dilakukan melalui perlindungan preventif dan perlindungan represif. ${ }^{13}$ Bentuk perlindungan hukum preventif bagi pemegang kartu uang elektronik dapat diwujudkan dengan pengaturan

${ }^{12}$ John Pieris dan Wiwik Sri Widiarty, 2007, Negara Hukum dan Perlindungan Konsumen Terhadap Produk Pangan Kedaluwarsa, Pelangi Cendikia, Jakarta, Hal 54.

${ }^{13}$ Menurut Philipus M. Hadjon bahwa ada dua bentuk perlindungan hukum bagi rakyat, yaitu perlindungan hukum preventif dan perlindungan hukum yang represif, yaitu :

a. Perlindungan Hukum Preventif

Perlindungan yang diberikan oleh pemerintah dengan tujuan untuk mencegah sebelum terjadinya pelanggaran.

b. Perlindungan Hukum Represif Perlindungan hukum yang bertujuan untuk menyelesaikan sengketa yang terjadi akibat perbedaan kepentingan.

Philipus M. Hadjon, 2007, Perlindungan Hukum Bagi Rakyat Indonesia, Percetakan M2 Print, Edisi Khusus, Surabaya, Hal 2. 
ketentuan tentang penggunaan perjanjian standar atau perjanjian baku yang lebih rinci mengenai hakekat, karakter, pembagian hak dan kewajiban yang dituangkan dalam bentuk undang-undang, yang memberi wadah atau tempat berlindung bagi pemegang kartu melalui pengaturan klausul-klausul dalam perjanjian baku syarat dan ketentuan pemegang kartu. Bentuk perlindungan represif dapat ditempuh oleh para pihak, baik penerbit maupun pemegang kartu melalui pola penyelesaian sengketa yang dapat dilakukan melalui pengadilan (litigasi) maupun upaya penyelesaian diluar pengadilan (non litigasi).

Bank Indonesia mengeluarkan Peraturan Uang Elektronik sebagai bentuk perlindungan hukum dalam mengatur dan mengawasi perkembangan uang elektronik yang diterbitkan dalam bentuk kartu oleh bank penerbit maupun bentuk lain yang diterbitkan oleh lembaga selain bank. Peraturan Bank Indonesia ini lebih lanjut mengatur mengenai persyaratan dan tata cara perolehan izin penyelenggara kegiatan e-money, pengaturan ini bertujuan untuk meningkatkan kelancaran dan efektivitas penyelenggaraan uang elektronik dan mencegah terjadinya pelanggaran terhadap penggunaan kartu e-money serta memberikan perlindungan bagi para pelaku dalam kegiatan uang elektronik khususnya pemegang kartu.

Bank Indonesia dalam rangka pencegahan pelanggaran uang elektronik melakukan pengawasan terhadap para pihak agar kegiatan uang elektronik dapat dilakukan secara efisien, cepat, aman dan andal dengan memperhatikan prinsip perlindungan nasabah pemegang kartu e-money. Pengawasan penyelenggaraan kegiatan uang elektronik difokuskan pada penerapan aspek manajemen risiko; kepatuhan terhadap ketentuan yang berlaku, termasuk kebenaran dan ketepatan penyampaian informasi dan laporan; dan penerapan aspek perlindungan nasabah.

Selain peraturan yang dikeluarkan oleh Bank Indonesia, penerbit juga menetapkan perjanjian baku berupa syarat dan ketentuan 
bagi pemegang kartu yang bertujuan memberikan pemahaman kepada pemegang kartu terhadap karakteristik uang elektronik untuk mencegah terjadinya penyalahgunaan kartu e-money sehingga kerugian pemegang kartu akibat kelalaian penggunaan kartu dapat dihindari.

\section{SIMPULAN DAN SARAN}

\section{Simpulan}

Berdasarkan pembahasan seperti yang telah diuraikan, maka dapat diambil suatu simpulan yaitu sebagai berikut :

1. Pengaturan alat pembayaran menggunakan uang elektronik (e-money) dalam melakukan transaksi e-money diatur oleh Bank Indonesia melalui Peraturan Bank Indonesia Nomor 11/12/PBI/2009 tentang Uang Elektronik (Electronic Money) termasuk diatur dalam Surat Edaran Bank Indonesia Nomor 11/11/DASP Tahun 2009 tentang Uang Elektonik
(Electronic Money).

Pengaturan ini mengatur mengenai tata cara dan syarat para pihak terkait kegiatan uang elektronik dalam menjalankan kegiatan uang elektronik. Lebih lanjut penerbit menentukan syarat dan ketentuan penggunaan kartu dalam bentuk perjanjian baku yang ditujukan kepada pemegang kartu. Dalam Undang-Undang

Perlindungan Konsumen, ditentukan pelarangan terhadap pencantuman klausula baku yang akan merugikan pemegang kartu selaku konsumen.

2. Perlindungan hukum bagi pemegang kartu dalam kegiatan pembayaran menggunakan uang elektronik (e-money) dilakukan melalui upaya perlindungan hukum secara preventif yaitu melalui aturan-aturan yang ditetapkan pemerintah maupun dalam bentuk perjanjian antara 
penerbit dan pemegang kartu e-money guna mencegah terjadinya pelanggaran dan melalui upaya represif yaitu penyelesaian sengketa melalui pengadilan maupun alternatif penyelesaian sengketa. Bank Indonesia selaku Bank Sentral akan melakukan pengawasan dalam proses pelaksanaan kegiatan penyelenggaraan uang elektronik yang dilakukan oleh penyelenggara (Prinsipal, Penerbit, Acquirer, Penyelenggara Kliring dan/atau Penyelenggara Penyelesaian Akhir) agar kegiatan pembayaran melalui uang elektronik dapat berjalan sesuai ketentuan berlandaskan prinsip perlindungan pemegang kartu. Bank Indonesia juga akan memberikan sanksi terkait pelanggaranpelanggaran yang dilakukan oleh penyelenggara kegiatan uang elektronik yang tidak dijalankan sesuai ketentuan yang berlaku.

\section{Saran}

Berdasarkan simpulan yang
telah diuraikan maka dapat
disampaikan saran terkait dengan
perlindungan hukum bagi pemegang
kartu uang elektronik dalam transaksi
e-money adalah:

1. Bentuk pengaturan lebih tegas terhadap perlindungan pemegang kartu dalam transaksi $e$-money yang dapat berupa Undang-Undang, Peraturan ataupun Perjanjian lainnya yang lebih jelas, lengkap dan memberikan persamaan kedudukan antara penerbit dan pemegang kartu.

2. Perlindungan hukum terhadap pemegang kartu e-money diharapkan dapat dilaksanakan pengawasannya oleh Bank Indonesia termasuk para penyelenggara kegiatan uang elektronik demi meningkatkan kelancaran dan keamanan bertransaksi bagi seluruh pihak terutama pemegang kartu. 


\section{DAFTAR PUSTAKA}

\section{Buku}

Abdulkadir Muhammad, 1992, Perjanjian Baku dalam Praktik Perusahaan Perdagangan, PT. Citra Aditya Bakti, Bandung.

Bank Indonesia, 2001, Paper Kajian E-Money, Bank Indonesia, Jakarta.

Edmon Makarim, 2004, Kompilasi Hukum Telematika, PT. RajaGrafindo Persada, Jakarta.

John Pieris dan Wiwik Sri Widiarty, 2007, Negara Hukum dan Perlindungan Konsumen Terhadap Produk Pangan Kedaluwarsa, Pelangi Cendikia, Jakarta.

Mariam Darus Badrulzaman, 1978, Perjanjian Kredit Bank, Alumni, Bandung.

N.H.T. Siahaan, 2005, Hukum Konsumen : Perlindungan Konsumen dan Tanggungjawab Produk, Panta Rei, Jakarta.

Niniek Suparni, 2009, CyberspacePeoblematika dan Antisipasi Pengaturannya, Sinar Grafika, Jakarta.

Philipus M. Hadjon, 2007, Perlindungan Hukum Bagi Rakyat Indonesia, Percetakan M2 Print, Edisi Khusus, Surabaya.

R. Serfianto DP, dkk, 2012, Untung dengan Kartu Kredit, Kartu ATM-Debit, \& Uang Elektronik, Visi Media, Jakarta.
Ronny Hanitijo Soemitro, 1995, Metodelogi Penelitian Hukum dan Jurimetri, Ghalia Indonesia, Jakarta.

Soerjono Seokanto dan Sri Mamuji, 2001, Penelitian Hukum Normatif Suatu Tinjauan Singkat, PT. Raja Grafindo Persada, Jakarta.

\section{Peraturan Perundang-}

\section{Undangan}

Kitab Undang-Undang Hukum Perdata (Burgerlijk Wetboek)

Undang-Undang Nomor 11 Tahun 2008 tentang Informasi dan Transaksi Elektronik

Undang-Undang Nomor 10 Tahun 1998 tentang Perbankan

Undang-Undang Nomor 3 Tahun 2004 juncto Undang-Undang Nomor 23 Tahun 1999 tentang Bank Indonesia

Undang-Undang Nomor 8 Tahun 1999 tentang Perlindungan Konsumen

Peraturan Bank Indonesia Nomor 10/8/PBI/2008 tentang Perubahan atas Peraturan Bank Indonesia Nomor 7/52/PBI/2008 tentang Penyelenggaraan Kegiatan Alat Pembayaran Menggunakan Kartu

Peraturan Bank Indonesia Nomor 11/11/PBI/2009 tentang Penyelenggaraan Kegiatan Alat Pembayaran Menggunakan Kartu 
Peraturan Bank Indonesia Nomor 14/2/PBI/2012 tentang

Penyelenggaraan Kegiatan Alat Pembayaran Menggunakan Kartu

Peraturan Bank Indonesia Nomor 11/12/PBI/2009 tentang Uang Elektronik (Electronic Money)

Surat Edaran Bank Indonesia Nomor 11/11/DASP Tahun 2009 tentang uang Elektronik (Electronic Money)

\section{BIODATA PENULIS}

Nama lengkap dengan gelar :

Ni Nyoman Anita Candrawati, SH., MH.

Alamat Rumah :

Jl. Kebo Iwa No. 4, Br. Robokan, Padang Sambian Kaja, Denpasar

HP :

081933112453

Alamat e-mail :

anitacandrawati@yahoo.com 